Archimer, archive institutionnelle de l'ffremer July 2008 ; Volume 60, Number 3 : Pages 253-271 http://www.ifremer.fr/docelec/

http://dx.doi.org/10.1007/s10874-009-9120-y

(c) 2008 Springer. Part of Springer Science+Business

Media

The original publication is available at http://www.springerlink.com

\title{
Rainfall chemistry: long range transport versus below cloud scavenging. A two-year study at an inland station (Opme, France)
}

\author{
Guillaume Bertrand ${ }^{1,{ }^{*}}$, Hélène Celle-Jeanton ${ }^{1}$, Paolo Laj $^{2}$, Jérôme Rangognio ${ }^{3}$ and Gilles Chazot ${ }^{4}$ \\ ${ }^{1}$ Université Clermont-Ferrand, Laboratoire Magmas et Volcans-CNRS UMR 6524, 5 rue Kessler, 63038 Cedex, \\ Clermont-Ferrand, France \\ ${ }^{2}$ Université Clermont-Ferrand, Laboratoire de Météorologie Physique-CNRS UMR 6016, II, 24 avenue des \\ Landais, 63170 Aubière, France \\ ${ }^{3}$ Centre National de Recherche Météorologique, 42 avenue Gaspard Coriolis, 31057 Toulouse, France \\ ${ }^{4}$ Université de Brest, CNRS, UMR 6538 Domaines Océaniques, Institut Universitaire Européen de la Mer, Place \\ Copernic, 29280 Plouzané, France
}

*: Corresponding author : G. Bertrand, email address : G.Bertrand@opgc.univ-bpclermont.fr

\begin{abstract}
:
The present study investigates the chemical composition of wet atmospheric precipitation samples on a daily and an intra-event timescales in Opme, an experimental meteorological station located near Clermont-Ferrand, France. The samples have been collected from November 2005 to October 2007. A total of 217 rainwater samples, integrated for $24 \mathrm{~h}$, were collected and analyzed for $\mathrm{pH}$, conductivity, $\mathrm{Na}^{+}, \mathrm{K}^{+}, \mathrm{Mg}^{2+}, \mathrm{NH}_{4}^{+}, \mathrm{Ca}^{2+}, \mathrm{Cl}^{-}, \mathrm{NO}_{3}^{-}, \mathrm{SO}_{4}{ }^{2-}, \mathrm{PO}_{4}{ }^{3-}$ and $\mathrm{HCO}_{3}^{-}$. The composition of the rainwater collected appeared to be controlled by the following potential sources: neutralisation process (association among calcium, ammonium with nitrate and sulphate), marine and terrestrial sources. In order to determine the role of long-range transport, the integrated events were classified according to four origins of air-masses: (1) West, (2) North and East, (3) South including Iberian and Italian Peninsulae and (4) local. This analysis allows identifying the source areas of the different association of elements defined. Although calcium is always dominant, total content of rainfall is variable and neutralisation process can be more or less efficient and specific. Rainout (long-range transport) and washout (below-cloud scavenging) were investigated through intra-event measurements of chemical species. Four rain-events have been selected according to the four classes of origins of air-masses. It appears that the first fractions are responsible for an important part of the chemical content of the whole event. Terrestrial species, locally emitted, induce the neutralisation process of acid species. Local meteorological conditions, such as wind's speed and direction, play an important role as they could provoke recharges of the below cloud air column during the event.
\end{abstract}

Keywords: Rainwater - Major ions - Sequential sampling - Air-mass back-trajectories - Chemistry France 
The chemical composition of precipitation is strongly linked with aerosols (both particles and gases) carried by rainwater (Junge, 1963). They are removed from the atmosphere by two scavenging processes (Meszaros, 1981; Huang et al., 2008): 1) the rainout corresponds to condensation processes within the clouds during their formation and travel, 2) the washout is characterized by the impaction with falling raindrops. In this way, the rainfall signature integrates both the long-range transport of chemical species by clouds and the local scavenging of atmospheric aerosols during the rain event. These figures vary strongly both from event to event and within a single event because rainout and washout proportions strongly depend on the environment of the sampling site (urbanized, rural or remote). It is a function of the aerosol loading and its vertical distribution in the lower atmosphere (Lim et al., 1991). Therefore the composition of rainwater depends both on the meteorological context, which influences clouds and rains characteristics and on local/long-range transport of aerosols and their spatial distribution (Durana et al., 1992). The sources of dissolved components in rainwater has often been classified in different categories based on air mass origin (Celle, 2000): 1) marine source which essentially provides $\mathrm{Na}^{+}$and $\mathrm{Cl}^{-}, 2$ ) terrestrial source e.g. soil dust $\left.\left(\mathrm{Ca}^{2+}, \mathrm{Mg}^{2+}, \mathrm{HCO}_{3}{ }^{-}\right), 3\right)$ anthropogenic sources e.g. traffic, industry, agriculture and burning of vegetation mainly associated with $\mathrm{NO}_{3}^{-}, \mathrm{K}^{+}, \mathrm{SO}_{4}{ }^{2-}, \mathrm{NH}_{4}^{+}$. Moreover the atmosphere constitutes a reactive medium. Some aerosols can interact to form new species in dry air before their dissolution in the meteoric water. This latter can also induces further reactions due to the presence of ionic species. These interactions result in a wide range of chemical composition, as well as in variations of $\mathrm{pH}$ (Berner and Berner, 1987; Cyrys et al., 1995).

Sources and chemical interactions are difficult to discriminate analytically but their relative 60 contributions could be estimated by a coupling of chemical composition and meteorological 
data (Beverland et al., 1998; Avila et Alarcon, 1999; Celle, 2000; Huang et al., 2008; CelleJeanton et al., 2009). In this purpose, 217 precipitation events and 204 infra-event samples have been collected during the November 2005-October 2007 period at Opme meteorological station (Massif Central, France) and were characterised as a function of their air mass backtrajectories.

The objectives of such an approach are: 1) to evaluate the role of the long-range transport and characterize the distant sources of aerosols and 2) to determine how local meteorological variables and environmental features could influence the chemical signature of rainwater at a small temporal scale.

\section{Methodology}

\section{Sampling site}

The sampling device has been settled at Opme meteorological station $\left(45^{\circ} 43^{\prime} \mathrm{N}, 3^{\circ} 5^{\prime} 30^{\prime \prime} \mathrm{E}, \mathrm{z}\right.$ $=650 \mathrm{~m}$ ) belonging to Observatoire de Physique du Globe de Clermont-Ferrand. The meteostation is located $8 \mathrm{~km}$ south of Clermont-Ferrand urban district, characterised by a population of 260000 inhabitants (INSEE, 1999), and which constitutes the main regional activity centre (industries, tertiary sector). Surrounding this area, land occupation mainly consists on cerealgrowing in the eastern part (Limagne basin) and on rearing or forest on the western part (Chaîne des Puys). The lithology mainly consists of sedimentary deposits on the Limagne basin and crystalline basement (volcanic and granitic) on the west (Fig.1).

In addition to the collection of rainwater, the recorded parameters are: rainfall intensity $(\mathrm{mm} / \mathrm{h})$, temperature $\left({ }^{\circ} \mathrm{C}\right)$, wind speed and direction. Daily rainfalls have been collected through an automatic precipitation collector (Eigenbrodt NSA $181 / \mathrm{KHS}$ ) with a $500 \mathrm{~cm}^{2}$ 
aperture. A precipitation sensor causes the cover device to open up the collection funnel at the start of precipitation and then avoids dry depositions in wet samples. Precipitation flows from the funnel down a bottle tray built in with 9 collecting bottles of 1 litre each (one bottle for each day of the week, the additional $9^{\text {th }}$ bottle is thought as an overflow for extremely high precipitation). When precipitation has ceased and after evaporation of the sensor surface, the funnel lids closed automatically. The system is refrigerated at $5{ }^{\circ} \mathrm{C}$ and allows a good conservation of samples that are collected once a week. After the sampling, the bucket is systematically cleaned with distilled water. It has to be noted that some events were not analysed for they are too small in volume (analyses require a minimum rainfall volume of 15 $\mathrm{ml}$ ). Moreover, due to the defection from the cover device, some events were not sampled. In spite of this, the sampling of $89 \%$ of the total rainy days of the period has been performed.

The sequential sampling of rainwater was carried out using a modified version of Bourrié's device (1978; Celle-Jeanton et al., 2004) which is located near the total rain collector. This collector of $1134 \mathrm{~cm}^{2}$ area is feeding a set of 10 vials of $100 \mathrm{ml}$ which are successively filled by the way of a three-way pipe. It enables the collection of rains up to $17.6 \mathrm{~mm}$. Laboratory tests assessed that mixing between successive vials is about 3\% (Rangognio, 2006).

\section{Analytical methods}

Upon sampling, the rainwater was taken to the laboratory where electrical conductivity (EC) and $\mathrm{pH}$ are measured with WTW Multi $340 \mathrm{i} . \mathrm{HCO}_{3}{ }^{-}$concentrations are determined by titration with a $5.10^{-4} \mathrm{M}$ solution of sulphuric acid. Samples were subsequently poured into standard $100 \mathrm{ml}$ polyethylene flask for further analysis and stored at $4^{\circ} \mathrm{C}$ for further chemical 110 analysis of anions $\left(\mathrm{SO}_{4}{ }^{2-}, \mathrm{Cl}^{-}, \mathrm{NO}_{3}{ }^{-}\right.$and $\left.\mathrm{PO}_{4}{ }^{3-}\right)$ and cations $\left(\mathrm{Ca}^{2+}, \mathrm{Na}^{+}, \mathrm{NH}_{4}^{+}, \mathrm{K}^{+}, \mathrm{Mg}^{2+}\right)$. Concentrations of ionic species were determined by ion chromatography, using a DIONEX 
DX320 chromatograph with a AS11 column for anions. This system uses an eluent generator to convert pure water into potassium hydroxide eluent through electrolysis for anions separations. A DIONEX ICS500 chromatograph with a CS16 column was used for cations determination. A methanesulfonic acid eluent was used for cation separations. The analysis method is similar than the one described by Jaffrezo et al. (1998) and Ricard et al. (2002). The flow rates of eluents were $1 \mathrm{ml} / \mathrm{min}$. The detection limits are $0.05 \mu \mathrm{eq} / 1$ for $\mathrm{Cl}^{-}, 0.1 \mu \mathrm{eq} / 1$ for $\mathrm{NO}_{3}{ }^{-}, 0.6 \mu \mathrm{eq} / 1$ for $\mathrm{SO}_{4}{ }^{2-}$ and $\mathrm{PO}_{4}{ }^{3-}, 0.06 \mu \mathrm{eq} / 1$ for $\mathrm{Na}^{+}, 0.04 \mu \mathrm{eq} / 1$ for $\mathrm{NH}_{4}{ }^{+}, 0.3 \mu \mathrm{eq} / 1$ for $\mathrm{K}^{+}$, $0.1 \mu \mathrm{eq} / 1$ for $\mathrm{Mg}^{2+}$ and $\mathrm{Ca}^{2+}$. The uncertainty of these chromatograh systems is $5 \%$. In order to assess the validity of the sampling device, blanks were determined for the analysed elements. The highest value were $1.0 \mu \mathrm{eq} / 1$ for sodium and $0.7 \mu \mathrm{eq} / 1$ for calcium, the other elements were not detected. The charge balance between anions and cations was assessed through linear regression analyses of the data. The results yield value of 0.93 for the regression coefficient indicating the completeness of measured parameters.

\section{Results and discussion}

\section{Rainfall main characteristics}

130 Table 1 shows the statistics calculated for the chemical parameters measured in the rain samples collected at Opme from Nov-2005 to Nov-2007. Minimum and the maximum values of each chemical parameter emphasize the high variability of the chemical composition and mineralization of rainwater. This variability can be due to the rain amount (Al-Momani et al., 1995; Khwaja and Husain, 1990; Hicks and Shannon, 1979) as can be seen on Fig. 2 or to the influence of various chemical sources. In this context, one way to keep out the influence of rain quantity is to use the volume-weighed mean of concentrations to characterize the general features of the precipitation chemistry. 
At Opme meteo-station, the volume-weighed mean $\mathrm{pH}$ is of 5.1, showing a tendency of slight acidity of rainwater. Generally, unpolluted precipitations are known to be weakly acid due to

140 their equilibrium with atmospheric $\mathrm{CO}_{2}$. Then, the $\mathrm{pH}$ of chemically undisturbed rainwater is about 5.7 (Berner and Berner, 1987). The acidic feature is common in industrialised countries (Tost et al., 2007) and is due to anthropogenic emissions such as $\mathrm{SO}_{\mathrm{x}}$ and $\mathrm{NO}_{\mathrm{x}}$. The volume weighted mean (VWM) concentrations of the major ionic species are in the following order: $\mathrm{Ca}^{2+}>\mathrm{HCO}_{3}{ }^{-}>\mathrm{NO}_{3}{ }^{-}>\mathrm{SO}_{4}{ }^{2-}>\mathrm{NH}_{4}{ }^{+}>\mathrm{Na}^{+}>\mathrm{Cl}^{-}>\mathrm{H}_{3} \mathrm{O}^{+}>\mathrm{Mg}^{2+}>\mathrm{K}^{+}>\mathrm{PO}_{4}{ }^{3-}$. Rainfalls chemistry

145 appears then to be mainly influenced by elements coming from terrestrial and anthropogenic sources. Except for $\mathrm{SO}_{4}{ }^{2-}$, Negrel and Roy (1998) found similar concentrations at SainteMarguerite site (12 km to the east from Opme). However concentrations of $\mathrm{SO}_{4}{ }^{2-}$ analysed during the period Nov-2005 to Nov-2007 are two times lower than the ones of SainteMarguerite measured in the period Mar-1994 to Apr-1995. This difference could be explained by the general decrease in sulphur emissions between 1986 and 2001 observed in Europe (Fowler et al., 2005); in Great Britain, the sulphate concentrations in rain drops decrease of $47 \%$ during the 1986-2001 period; in continental Europe reductions in $\mathrm{SO}_{2}$ emissions of decrease by $72 \%$ during the same period.

\section{Source and processes affecting the rainwater mineralization}

To evaluate the main geochemical sources of dissolved compounds in the rainwater, interspecies relationships could be investigated through a multivariate statistical analysis. A factorial analysis coupled with varimax rotation permits to determine the preferential association between the chemical species in rain (Plaisance et al., 1996; Simeonov et al., 2003; Zunckel et al., 2003). Principle factor analysis was applied to the 217 chemical analyses. Consecutive factors are uncorrelated or orthogonal to each other. Factor loadings correspond to the correlations of each variable with the factor. Therefore, the more the 
absolute value approaches one, the more the variable is correlated with the factor. A negative

165 variable loading indicates that it varies in opposite direction to the variables with positive signs. Three factors have been used in this analysis, giving each variable a loading within each factor. Loadings greater than 0.5 are considered to be significant components of the factor.

170 The three factors explain $99.7 \%$ of the total variance of all the data (Table 2). The first factor (41.7\% of the total variance) suggests the association of anthropogenic species $\left(\mathrm{NO}_{3}{ }^{-}, \mathrm{SO}_{4}{ }^{2-}\right.$, $\left.\mathrm{NH}_{4}^{+}\right)$with $\mathrm{Ca}^{2+}$ mainly of a terrestrial origin. The relatively high loading in $\mathrm{Mg}^{2+}(0.480)$ allows associating this element to factor 1, that then represents neutralisation process. In fact, these well-correlations between ions result from atmospheric chemical reactions, probably

175 from the reaction of the $\mathrm{H}_{2} \mathrm{SO}_{4}$ and $\mathrm{HNO}_{3}$ acids with alkaline compounds rich in $\mathrm{Ca}^{2+}$ and $\mathrm{Mg}^{2+}$ carried into the atmosphere. Neutralisation of $\mathrm{HNO}_{3}$, and $\mathrm{H}_{2} \mathrm{SO}_{4}$ by soil-derived particles and by ammonia emissions can form aerosols such as $\mathrm{NH}_{4} \mathrm{HSO}_{4},\left(\mathrm{NH}_{4}\right)_{2} \mathrm{SO}_{4}$, $\mathrm{NH}_{4} \mathrm{NO}_{3}, \mathrm{Ca}\left(\mathrm{NO}_{3}\right)_{2}$ and $\mathrm{CaSO}_{4}$ (Sisterson, 1989; Hov and Hjollo, 1994). The second factor (35.6\% of the total variance) highlights the association of $\mathrm{Na}^{+}, \mathrm{Cl}^{-}$and $\mathrm{Mg}^{2+}$ and then 180 corresponds to the marine origin. The third factor associates calcium and bicarbonates $(22.4 \%$ of the total variance). This factor 3 expresses the control of the terrestrial source that could influence the alkalinity of the atmospheric water due to carbonate dissolution.

Many studies pointed out the role of meteorological factors in determining the chemical features of precipitations (Beverland et al., 1998; Avila and Alarcon, 1999; Celle-Jeanton et 185 al., 2009). To investigate the origin of components, the chemical content of the 217 precipitation events sampled during our study have been coupled with the corresponding air mass back trajectories. 
Air mass back trajectories were calculated for each sample by using the NOAA HYbrid Single-Particle Lagrangian Integrated Trajectory Version 4 (HYSPLIT4) model (Draxler and Rolph, 2003; Rolph, 2003). The back trajectories were calculated for a three days period and for three altitudes: 900 m, $1500 \mathrm{~m}$ and $3000 \mathrm{~m}$. Dataset of winds' speed and direction (1981195 2000, MétéoFrance) allows calculating the main air masses origin and thus permits to approach the weather patterns of Clermont-Ferrand. Four main transport patterns have been segregated: sector 1 that consists of air masses coming mainly from Atlantic Ocean $(22.5 \%$ of air-masses origin), sector 2 that corresponds to Northern and Central Europe (28.3\%), sector 3 towards the South including Iberian Peninsula and Northern Africa (25.8\%), a regional sector 2004 , with a corresponding wind's speed lower than $2 \mathrm{~m} / \mathrm{s}$, corresponds to $22.4 \%$ (Fig. 3). Chemical contents for each sector were determined taking into account the role of the different sources of mineralization highlighted by the factor analysis previously depicted. In particular, some ions result from the contribution of both sea-salts (ss) aerosols and non-seasalt (nss) species. The sea-salt input is determined by assuming that all $\mathrm{Na}^{+}$(Brewer, 1975) is

205 provided by the marine source and that the proportionate amount of ions as $\mathrm{Cl}^{-}, \mathrm{SO}_{4}{ }^{2-}, \mathrm{Mg}^{2+}$, $\mathrm{K}^{+}, \mathrm{Ca}^{2+}$, are derived from sea salts.

Statistical results and distribution of $\mathrm{pH}$ are presented on Table 3 and Fig. 4, respectively. In order to determine the preferential neutralisation process, the linear regression between $\mathrm{nssCa}^{2+}$ (provided by terrestrial dusts such as $\mathrm{CaCO}_{3}$ or $\left.\mathrm{CaMg}\left(\mathrm{CO}_{3}\right)_{2}\right)$ or $\mathrm{NH}_{4}^{+}$with acidic 210 species $\left(\mathrm{NO}_{3}{ }^{-}\right.$and $\left.\mathrm{nsSSO}_{4}{ }^{2-}\right)$ are reported on Fig. 5.

The chemical content of rainfalls coming from sector 1 is dominated by non sea-salt calcium $\left(\mathrm{nssCa}^{2+}=23.9 \mu \mathrm{eq} / \mathrm{l}\right)$ and bicarbonates $(24.1 \mu \mathrm{eq} / 1)$, but is also influenced by anthropogenic species $\left(\left[\mathrm{NH}_{4}{ }^{+}\right]=20 \mu \mathrm{eq} / 1,\left[\mathrm{nssSO}_{4}{ }^{2-}\right]=16.8 \mu \mathrm{eq} / 1,\left[\mathrm{NO}_{3}{ }^{-}\right]=16.0 \mu \mathrm{eq} / \mathrm{l}\right)$. Sodium and 
215 chloride concentrations show the influence air masses coming from the Atlantic Ocean. Whereas a major marine source could be expected featuring atlantic events, it comes out that terrestrial and anthropogenic sources mark their chemical feature. This observation is in good agreement with the study of Rahn et al. (1982), who show that aged maritime air masses often contain a high proportion of submicron crustal and anthropogenic particles due to their long atmospheric residence times. The high content of calcium in rainfall was also shown, for rain events on the Atlantic coast, by Beysens et al. (2006) who indicated that the source of high concentration in calcium could be due to the removal of soils particles but also originate from agriculture activities. It would be consistent with VWM ammonium concentrations (20.0 $\mu$ eq/1). Although 4 samples are acidic $(\mathrm{pH}<4.5)$ and 9 have $\mathrm{pH}>6.5,31$ events have a nearly neutral pH. Fig. 5 shows the good relationships between $\mathrm{nsSCa}^{2+}$ and $\left(\mathrm{NO}_{3}{ }^{-}+\mathrm{nssSO}_{4}{ }^{2-}\right), \mathrm{NH}_{4}{ }^{+}$ and $\left(\mathrm{NO}_{3}{ }^{-}+\mathrm{nssSO}_{4}{ }^{2-}\right), \mathrm{R}=0.77$ and 0.74 , respectively, and attests consequently that neutralisation can frequently occur in air-masses coming from the sector 1.

Rainwater coming from the sector 2 presents high concentrations of $\mathrm{NO}_{3}{ }^{-}, \mathrm{nssSO}_{4}{ }^{2-}$ and $\mathrm{NH}_{4}{ }^{+}$ 230 (respectively $52.3 \mu \mathrm{eq} / 1,35.6 \mu \mathrm{eq} / 1,33.3 \mu \mathrm{eq} / 1$, Table 3 ) and the highest total mineralization of the four sectors. This group also exhibits the highest VWM in non sea-salt calcium (53.2 $\mu$ eq/l) due probably to the removal of Ca-rich dusts. Such influence was highlighted by Sanusi et al. (1996) in northern France; they particularly pointed out the role of loess that can be easily removed from the Alsatian basin. High mineralization correlated to high content in 235 anthropogenic components let appear that condensation nuclei are numerous and mainly constituted of polluted aerosols. An increase in cloud condensation nuclei concentration causes an increase in the number of cloud droplets (Reade et al., 2006).

Low mean $\mathrm{pH}$ of 4.8 , (Table 3, Fig. 4) indicates potential acid influences of air-masses coming from this sector. This feature is consistent with the low value of correlation 
coefficient $\left(\mathrm{R}=0.46\right.$, Fig. 5) between $\mathrm{nssCa}^{2+}$ and $\left[\mathrm{NO}_{3}{ }^{-}+\mathrm{nssSO}_{4}{ }^{2-}\right]$. Concerning the interaction between $\mathrm{NH}_{4}{ }^{+}$and $\left[\mathrm{NO}_{3}{ }^{-}+\mathrm{nsSSO}_{4}{ }^{2-}\right]$, the correlation is better $(\mathrm{R}=0.73)$, showing a preferential neutralisation with this element. However, the low slope of this relation $(a=0.15)$ and the acid $\mathrm{pH}$ distribution (Fig. 4) may indicate that it is poorly effective. These observations are reliable with the results of Plaisance et al. (1997) who show the existence of 245 important sources of $\mathrm{NO}_{2}$ and $\mathrm{SO}_{2}$ in the industrial and urban regions of northern and central Europe, showing the importance of anthropogenic emissions to the high acid events that occur in France.

The chemistry of rainfall events from sector 3 is dominated by non sea-salt calcium $(28.4$ $250 \mu \mathrm{eq} / \mathrm{l})$ and bicarbonate $(26.6 \mu \mathrm{eq} / 1)$, which could be attributed to dissolution of calcareous dust in rain originated from Mediterranean region (Plaisance et al., 1996; Avila et al., 1997; Avila et al., 1998). The weighted mean concentration of ammonium, non-sea-salt sulphates and nitrates are relatively low: $17.2 \mu \mathrm{eq} / 1,16.0 \mu \mathrm{eq} / 1,16.9 \mu \mathrm{eq} / 1$, respectively. Distribution of $\mathrm{pH}$ is similar to the one of sector 1 . For these two groups, the neutralisation effect maintains $255 \mathrm{pH}$ close to the neutral threshold. Fig. 5 indicates that neutralisation is mainly due to $\mathrm{NH}_{4}^{+}(\mathrm{R}$ $=0.86$ ) for sector 3 . Weak concentrations in anthropogenic components are not in agreement with the observation of Ezcurra et al. (1988) and Diaz-Caneja et al. (1989). These authors quoted that polluted rains for northern Spain were mostly associated to industrial sources in Southern France and Northern Spain. This difference could be explained by the presence of 260 the Cevennes massif located between Mediterranean area and sampling site and that plays the role of an orographic barrier. Such hypothesis is consistent with the low concentration in marine species. Indeed, if air-masses from the South are partially stopped and precipitated, it would mean that most of clouds precipitating at Opme were supplied by closer sources of 
aerosols mainly emitting calcareous material. This assumption is reliable with the proportion 265 between $\mathrm{nssCa}^{2+}$ and the acidic species $(\mathrm{a}=0.93)$.

Sector 4 is represented by rainfalls events produced by local influences. This group present high weighted mean value in non-sea-salt calcium $(36.8 \mu \mathrm{eq} / 1)$, bicarbonates $(32.2 \mu \mathrm{eq} / 1)$, non-sea-salt sulphates $(31.0 \mu \mathrm{eq} / \mathrm{l})$, ammonium $(31.8 \mu \mathrm{eq} / \mathrm{l})$ and nitrates $(29.7 \mu \mathrm{eq} / \mathrm{l})$. This tendency underlines the influence of the local environment, as Opme is located near Clermont-Ferrand urban district and Limagne basin that could also provide anthropogenic and terrestrial material from cultivated lands. Sea-salt chloride and sodium present the lowest mean concentration ( 8.0 and $8.6 \mu \mathrm{eq} / 1$, respectively) of the four sectors, due to the inland origin of air-masses. Correlation coefficients between $\left[\mathrm{NO}_{3}{ }^{-}+\mathrm{nssSO}_{4}{ }^{2-}\right] / \mathrm{nssCa}^{2+}(\mathrm{R}=0.74)$ and $\left[\mathrm{NO}_{3}{ }^{-}+\mathrm{nsSSO}_{4}{ }^{2-}\right] / \mathrm{NH}_{4}{ }^{+}(\mathrm{R}=0.77)$ show that neutralisation is non-specific for sector 4 and explain that more than $50 \%$ of the events of sector 4 present a $\mathrm{pH}>5.5$.

Neutralisation processes during air masses travel are then very efficient, especially for sectors 1,3 and 4 due to intervention of $\mathrm{nssCa}^{2+}$ and $\mathrm{NH}_{4}{ }^{+}$that act together. Concerning the sector 2 , 280 the weak neutralisation of acidity could be due to the weak proportion of $\mathrm{NH}_{4}^{+}$content according with acidic species. Moreover, the dissolution of ammonium could lead to enhance the solubility of $\mathrm{SO}_{2}$. This could constitute a negative feedback on the neutralisation process (Finlayson-Pitts et Pitts, 1986). $\mathrm{Ca}^{2+}$ appears to be the dominant ion of all the sectors. Then, among specific characteristics of each sectors, observation show the importance of long-range transport on rainfall chemistry at Opme météo-station.

\section{Influence of local scavenging: washout}


Sequential sampling enables the investigation of the variability of the chemical composition, and thus the evaluation of scavenging processes (rainout or washout) during rain events (Meszaros, 1981; Seymour and Stout, 1983; Durana et al., 1992; Lim et al., 1991; Pelicho et al., 2006; Germer et al., 2007; Celle-Jeanton et al., 2009). For this purpose, 29 rain events were sampled during the period Dec 2005- May 2006 using a sequential rain collector.

Our purpose is to follow the evolution of rainfall chemistry during rain event and to determine 295 the local contribution during washout. Taking into account the whole data set, Fig. 6 shows that the decrease of concentration concerns all the measured species, except $\mathrm{H}_{3} \mathrm{O}^{+}$. An average of $53 \%$ of the total mineralization is removed in the first three fractions (precipitation height $=$ $2.6 \mathrm{~mm}$ ), this value varies from $28 \%$ to $76 \%$. This indicates that the below cloud scavenging generally dominates the removal of atmospheric components in the region. Then a further 300 gradual drop to approximately constant values is observed and represents the in-cloud processes contribution to rainwater chemistry (Gonçalves et al., 2002).

In order to understand associations between chemical species during events and to determine the role of meteorological features, four of these 29 rainfalls have been selected according to 305 their similar rainwater amount (between 7.1 and $9.7 \mathrm{~mm}$ ) and air mass back trajectory: rainfall of $23-24 / 03 / 2006$ belonging to sector $1,11 / 04 / 2006$ to sector $2,06 / 05 / 2006$ to sector 3 , 07/05/2006 to local sector. Table 4 presents statistics of rainfall amount, electrical conductivity, $\mathrm{pH}$, direction (in degree, $0^{\circ}$ is the North; $180^{\circ}$ the South) and speed of wind for each selected event. Fig. 7, 8, 9 and 10 show the evolution of rainfall height and chemical 310 content during the 4 selected rain events.

The first fraction of the 23-24/03/06 event, coming from sector 1 (Fig. 7), is characterised by the dominance of the $\mathrm{NO}_{3}{ }^{-}, \mathrm{nssSO}_{4}{ }^{2-}$ and $\mathrm{NH}_{4}{ }^{+}(49 \%)$ whereas $\mathrm{nsSCa}^{2+}, \mathrm{nssMg}^{2+}$ and $\mathrm{HCO}_{3}{ }^{-}$ 
account for $29 \%$ and $\mathrm{Na}^{+}$associated with $\mathrm{ssCl}^{-}$and sea-salt fractions of $\mathrm{Cl}^{-}, \mathrm{SO}_{4}{ }^{2-}, \mathrm{Ca}^{2+}, \mathrm{Mg}^{2+}$,

$315 \mathrm{~K}^{+}$for $22 \%$. Last fraction of sector 1 is dominated by the terrestrial source $(45 \%)$. This could be due to local anthropogenic influences. The relatively low acidity measured in all the subsamples could be explained by neutralisation process by terrestrial species. Marine contribution is almost constant; a small decrease could be quoted from the beginning of the rain-event $(22 \%)$ to the end $(19 \%)$.

First and last fractions of the 11/04/2006 event, coming from sector 2 (Fig. 8), show a predominance of anthropogenic components. In between, from fractions 4 to 6 , contribution of anthropogenic source decreases whereas marine and terrestrial source supplies are relatively constant. At the end of the event, an increase in $\mathrm{NO}_{3}{ }^{-}, \mathrm{NH}_{4}{ }^{+}, \mathrm{nssSO}_{4}{ }^{2-}$ and $\mathrm{H}_{3} \mathrm{O}^{+}$and 325 the absence of decrease of the rainfall intensity may indicate a local recharge of anthropogenic and terrestrial species. The significant value of the wind speed during the event $(5.5 \mathrm{~m} / \mathrm{s})$ coming from the North would indicate the influence of Clermont-Ferrand urban district. Moreover a rapid raise of the acidity is observed at the end of the event and attests that neutralisation of acidity can be observed preferentially at the beginning of a precipitation event due to carbonate dissolution.

The first fraction of the 06/05/2006 event, coming from sector 3 (Fig. 9), is marked by high $\mathrm{NO}_{3}{ }^{-}, \mathrm{nssSO}_{4}{ }^{2-}, \mathrm{nssCa}^{2+}$ and $\mathrm{HCO}_{3}{ }^{-}$content. The first sub-sample is the result of little rainfall episodes occurring before the beginning of the major part of precipitation. The chemical 335 content decreases from fraction 1 to 5 . An interruption of the rain, between $13 \mathrm{~h} 15$ and $13 \mathrm{~h} 45$, allows a reloading of the below-cloud atmosphere that affects more peculiarly anthropogenic components. This fact can be related to a possible contribution of local sources of pollutants or a reloading of clouds by long range transported components; although the air-mass that 
generates the whole event of the 06/05/2006 is coming from the South, for the period comprised from $13 \mathrm{~h}$ and $14 \mathrm{~h} 30$, the wind comes from the North.

The 07/05/2006 event due to local weather pattern (Fig. 10) shows high concentrations in $\mathrm{HCO}_{3}{ }^{-}$and $\mathrm{NH}_{4}{ }^{+}$. From the beginning to the end of the rainfall event, concentrations of all components decrease, except $\left[\mathrm{H}_{3} \mathrm{O}^{+}\right]$. This indicates an efficiency of the below cloud

345 scavenging process. Increasing acidity can be due to the removal of carbonated species below cloud as it can be seen with the decrease of non sea-salt calcium, bicarbonates and ammonium. Indeed, the concentration of this latter is three times lower at the end of the event than in the first sample.

The slight increase of the concentrations in $\mathrm{NO}_{3}{ }^{-}, \mathrm{NH}_{4}{ }^{+}, \mathrm{nsSSO}_{4}{ }^{2-}$ for the $7^{\text {th }}$ and the $8^{\text {th }}$ 350 samples corresponds to lower rainfall intensity (e.g. coming from less diluted parts of cloud) whereas concentrations in other components remain constant. This implies a great contribution of anthropogenic species as long-range aerosol loading i.e. condensation nuclei.

Changes in solute concentrations over time within events are likely to be a function of the 355 relative fraction of fine to coarse aerosols (Germer et al., 2007). The fine aerosol fraction $(<5$ $\mu \mathrm{m}$ ) is predominant within clouds and responsible for rainout (Lim et al., 1991), while the coarse fraction of aerosols, which is subject to gravitational deposition, is more important in washout (Seinfeld and Pandis, 1998; Saha and Moorthy, 2004). Indeed, the collection efficiency varies mainly with the size of the aerosol particles (Chate and Kamra, 1997; Chate

360 et al., 2003). Gaseous species such as $\mathrm{NO}_{\mathrm{x}}, \mathrm{SO}_{\mathrm{x}}$ and $\mathrm{NH}_{3}$ are then predominantly removed during in-cloud processes, whereas coarse mode (terrestrial species) is efficiently deposited during washout. Wet deposition of $\mathrm{H}_{3} \mathrm{O}^{+}$increases during the event, the highest part being deposited in the last precipitation sample fractions. This increasing acidification may be due 
to the high neutralisation effect at the beginning of the event. This effect can happen when

365 raindrops impact and dissolve atmospheric particles containing alkaline substances, especially carbonates.

Neutralising species can be also associated with $\mathrm{NO}_{3}{ }^{-}, \mathrm{nsSSO}_{4}{ }^{2-}$ and $\mathrm{NH}_{4}{ }^{+}$, forming $\mathrm{NH}_{4} \mathrm{NO}_{3}$, $\left(\mathrm{NH}_{4}\right)_{2} \mathrm{SO}_{4} \mathrm{Ca}\left(\mathrm{NO}_{3}\right)_{2}, \mathrm{CaSO}_{4}$, as can be seen from the important flux of anthropogenic species such as non sea-salt calcium in the first sample. It would be consistent with the fact that anthropogenic species remain an important source and that acidity flux is low at the beginning of the event. This fact is linked to the acidity evolution during the four events. The major $\mathrm{H}_{3} \mathrm{O}^{+}$flux occurs during the last fractions of the rainfall event. The rural environment of Opme consists of agriculture land and calcareous Oligocene fields and is then an important source of neutralising species (calcium carbonate). This local characteristic may justify the dominance of calcium in the composition of rain coming from the four air-masses patterns. The proximity of Clermont-Ferrand agglomeration can also induce anthropogenic feature of the rainwater at the beginning or during the event. These facts highlight the importance of local meteorological conditions (speed and direction of wind, humidity of ground) to understand chemical signature of a single rain event.

\section{Conclusion}

Based on 217 rain samples, this study primarily shows that rainfall chemistry at Opme meteostation is dominated by terrestrial elements with a quite neutral $\mathrm{pH}$. The statistical approach through a factor analysis, revealed that neutralisation is the main process affecting the rainwater chemistry, in agreement with $\mathrm{pH}$ measurements. 
Taking into account the main air-masses pattern at Opme, this work reveals differences in solute concentrations according to geographical long-range origin. Indeed, whereas sector 1 (Atlantic) and sector 3 (Mediterranean) events are the most diluted, the concentrations increase markedly in the events coming from the sector 4 (local) and the sector 2 (Northern and Eastern Europe). This is probably due to the high flux of aerosols in this industrial area of Europe. In particular it was shown that nitrate and acidity are preferentially carried by these rain events. The highest concentrations of marine species $\left(\mathrm{Na}^{+}, \mathrm{ssCl}^{-}\right)$and in $\mathrm{nssCa}^{2+}$ are also measured for sector 2. Concerning the neutralisation, it was demonstrated that this process is unspecific (involving both $\mathrm{nssCa}^{2+}$ and $\mathrm{NH}_{4}{ }^{+}$) for sector 1,3 and 4 , but it concerns only $\mathrm{NH}_{4}{ }^{+}$ for sector 2. This characteristic can restrain the neutralisation process and account for the acid $\mathrm{pH}$ distribution of this last sector.

Considering the chemical variability during four single events, it appears that the major part of chemical content is scavenged during the three first fractions of the rainfall. This highlights the great influence of washout on the final composition of the rainwater. It especially contributes to the deposition of large terrestrial aerosols, which neutralise acidity of the first fractions of rainwater and anthropogenic species coming from Clermont-Ferrand urban district. Then, at an infra-event scale, local meteorological phenomena could strongly alter the long-range signatures and account for leading factors of chemical variability of the meteoric water. 


\subsubsection{Aknowledgments}

The authors thank the PREVOIR project financed by the Auvergne region for its material support and gratefully acknowledge the NOAA Air Resources Laboratory (ARL) for the provision of the HYSPLIT transport and dispersion model and/or READY website (http://www.arl.noaa.gov/ready.html) used in this publication. 


\section{References}

Al-Momani, I.F., Ataman, O.Y., Anwar, M.A., Tuncel, S., Kös, C., Tuncel, G.: Chemical composition of precipitation near an industrial area at Izmir, Turkey. Atmospheric Environnent 29, 1131-1143 (1995)

Avila, A., Queralt-Mitjans, I., Alarcon, M.: Mineralogical composition of African dust delivered by red rains over northeastern Spain. Journal of Geophysical Research 102, (D18), 21, 977-996 (1997)

Avila, A., Alarcon, M., Queralt-Mitjans, I.: The chemical composition of dust transported in red rains and its contribution to the biogeochemical cycle of a holm oak forest in Catalonia (Spain). Atmospheric Environment 32, 179-191 (1998)

Avila, A., Alarcon, M.: Relationship between precipitation chemistry and meteorological situations at a rural site in N.E. Spain. Atmospheric Environment 33, 1663-1677 (1999)

Berner, E., Berner, R.: The Global Water Cycle. Prentice Hall, New Jersey (1987)

Beverland, I.J., Crowther, J.M., Srinivas, M.S.N., Heal, M.R.: The influence of meteorology and atmospheric transport patterns on the chemical composition of rainfall in south-east England. Atmospheric Environment 32, 1039-1048 (1998)

Beysens, D., Ohayon, C., Muselli, M., Clus, O.: Chemical and biological characteristics of dew and rain water in an urban coastal area (Bordeaux, France). Atmospheric Environment 40, 3710-3723 (2006)

Bourrié, G. : Acquisition de la composition chimique des eaux en climat tempéré. Application aux granites des Vosges et de la Margeride. PhD Thesis, Université Louis Pasteur, Strasbourg (1978) 
Celle, H. : Caractérisation des précipitations sur le pourtour de la Méditerranée occidentale. Approche isotopique et chimique. PhD Thesis, Université Avignon et Pays de Vaucluse (2000)

Celle-Jeanton, H., Gonfiantini, R., Travi, Y., Sol, B.: Oxygen-18 variations of rainwater during precipitation: application of the Rayleigh model to selected rainfalls in Southern France. Journal of Hydrology 289, 165-177 (2004)

Celle-Jeanton, H., Travi, Y., Loye-Pilot, M.D., Huneau, F., Bertrand, G.: Rainwater chemistry at a Mediterranean inland station (Avignon, France): local contribution versus long range supply. Atmospheric Research 91, 118-126 (2009)

Chate, D..M., Kamra, A.K.: Collection efficiencies of large water drops collecting aerosol particles of various densities. Atmospheric Environment 31, 1631-1635 (1997)

Chate, D.M., Rao, P.S.P., Naik, M.S., Momin, G.A., Safai, P.D., Ali, K.: Scavenging of aerosols and their chemical species by rain. Atmospheric Environment 37, 2477-2484 (2003)

Cyrys, J., Gutschmidt, K., Brauer, M., Dumyahn, T., Heinrich, J., Spengler, J.D., Wichmann, H.E.: Determination of acidic sulfate aerosols in urban atmospheres in Erfurt (F.R.G.) and Sokolov (Former C.S.S.R). Atmospheric Environment 29, 3545-3557 (1995)

Diaz-Caneja, N., Bonet, A., Gutierrez, I., Martinez, A., Villar E.: The chemical composition of rainfall in a city of northern Spain. Water, Air, and Soil Pollution 43, 277-291 (1989)

Durana, N., Casado, H., Ezcurra, A., Garcia, C., Lacaux, J.P., Pham Van Dinh: Experimental study of the scavenging process by means of a sequential precipitation collector, preliminary results. Atmospheric Environment 26A, 13, 2437-2443 (1992)

Draxler, R.R., Rolph, G.D.: HYSPLIT (HYbrid Single-Particle Lagrangian Integrated Trajectory) Model access via NOAA ARL READY Website (http://www.arl.noaa.gov/ ready/hysplit4.html). NOAA Air Resources Laboratory, Silver Spring, MD (2003) 
Ezcurra, A., Casado, H., Lacaux, J.P., Garcia, C.: Relationship between meteorological situations and acid rain in Spanish Basque country. Atmospheric Environment 22, 2779-2786 (1988)

Fowler, D., Smith, R.I., Muller, J.B.A., Hayman, G., Vincent, K.J.: Changes in the atmospheric deposition of acidifying compounds in the UK between 1986 and 2001. Environmental Pollution 137, 15-25 (2005)

Finlayson-Pitts, B.J., Pitts, J.N.: Atmospheric chemistry-Fundamentals and experimental techniques. Wiley, New-York (1986)

Germer, S., Neill, C., Krusche, A.V., Gouveia Neto, S.C., Elsenbeer, H.: Seasonal and withinevent dynamics of rainfall and throughfall chemistry in an open tropical rainforest in Rondonia, Brazil. Biogeochemistry 86, 155-174 (2007)

Gonçalves, F.L.T, Ramos, A.M., Freitas, S., Silva Dias, M.A., Massambani, O.: In-cloud and below-cloud numerical simulation of scavenging processes at Serra do Mar Region, SE Brazil. Atmospheric Environment 36, 5245-5255 (2002)

Hicks, B.B., Shannon, J.D.: A method for modelling the deposition of sulphur by precipitation over regional scales. Journal of Applied Meteorology 18, 1415-1420 (1979)

Hov, O., Hjollo, B.A.: Transport distance of ammonia and ammonium in northern Europe. Its relation to emissions of $\mathrm{SO}_{2}$, and $\mathrm{NO}_{\mathrm{x}}$. J. Geophys. Res. 99, 749-755 (1994)

Huang, K., Zhuang, G., Xu, C., Wang, Y., Tang, A. : The chemistry of the severe acidic precipitation in Shanghai, China. Atmospheric Research 89, 149-160 (2008)

INSEE : Recensement de mars 1999 de l'Institut National de la Statistique et des Etudes Economiques. www.recensement.insee.fr (1999). Accessed 20 June 2007

Jaffrezo, J.L., Colas, N. and Bouchet, M.: Carboxylic acids measurements with ionic chromatography. Atmospheric Environment 32 (14-15), 2705-2708 (1998) 
Junge, C.E.: Air chemistry and radioactivity. Academic Press, New-York (1963)

Khwaja, H.A., Husain, L.: Chemical characterization of acid precipitation in Albany, New York. Atmospheric Environment 24A, 1869-1882 (1990)

Lim, B., Jickells, T.D., Davies, T.D.: Sequential sampling of particles, major ions and total trace metals in wet deposition. Atmospheric Environment 25A, 3-4, 745-762 (1991)

Meszaros, E.: Atmospheric chemistry. Fundamental aspects. Studies in Environmental Science 11. (1981)

Negrel, P., Roy, S.: Chemistry of rainwater in the Massif Central (France): a strontium isotope and major element study. Applied Geochemistry, 13, 8, 941-952 (1998)

Pelicho, A.F., Martins, L.D., Nomi, S.N., Solci, M.C.: Integrated and sequential bulk and wetonly samplings of atmospheric precipitation in Londrina, South Brazil (1998-2002). Atmospheric Environment 40, 6827-6835 (2006)

Plaisance, H., Coddeville, P., Guillermo, R., Roussel, I.: Spatial variability and source identification of rural precipitation chemistry in France. The Science of the Total Environment 180, 257-270 (1996)

Plaisance, H., Galloo, J.C. Guillermo, R.: Source identification and variation in the chemical composition of precipitation at two rural sites in France. The Science of the Total Environment 206, 79-93 (1997)

Rahn, K.A., Brosset, C., Ottar, B., Patterson, E.M.: Black and White episodes, chemical evolution of Eurasian air masses and long range transport of carbon into the Arctic. In Particulate Carbon: Atmospheric Life Cycle, Wolff, T., Klimmish, R.L., (eds),., pp. 339-340. Plenum, New York (1982)

Rangognio, J. : Apport des mesures chimiques infra-événementielles dans la compréhension des mécanismes d'acquisition de la chimie des précipitations. Master Research Report, Université Clermont-Ferrand (2006) 
Reade, L., Jennings, S.G., McSweeney, G.: Cloud condensation nuclei measurements at Mace Head, Ireland, over the period 1994-2002. Atmospheric Research 82, 610-621 (2006)

Ricard, V., Jaffrezo, J.L., Kerminen, V.M., Hillamo, R.E., Sillanpaa, M., Ruellan, R., Liousse, C. and Cachier, H.: Two years of continuous aerosol measurements in northern Finland. Journal of Geophysical Research 107(D11) (2002).

Rolph, G.D.: Real-time Environmental Applications and Display sYstem (READY) Website (http://www.arl.noaa.gov/ready/hysplit4.html). NOAA Air Resources Laboratory, Silver Spring, MD (2003)

Saha, A., Moorthy, K..K.: Impact of precipitation on aerosol spectral optical depth and retrieved size distributions: a case study. J Appl Meteorol 43, 902-914 (2004)

Sanusi, A., Wortham, H., Millet, M., Mirabel, P.: Chemical composition of rainwater in eastern France. Atmospheric Environment 30, 1, 59-71 (1996)

Seinfeld, J.H., Pandis, S.N.: Atmospheric chemistry and physics: from air pollution to climate change. Wiley, New York (1998)

Seymour, M.D., Stout, T.: Observations of the chemical composition of rain using a short sampling times during a single event. Atmospheric Environment 17, 8, 1483-1487 (1983)

Simeonov, V, Kalina, M., Tsakovski, S., Puxbaum, H.: Multivariate statistical study of simultaneously monitored cloud water, aerosol and rainwater data from different elevation levels in an alpine valley (Achenkirch, Tyrol, Austria). Talanta 61, 519-528 (2003)

Sisterson, D.L.: A method for evaluation of acidic sulphate and nitrate in precipitation. Water Air Soil Pollut. 43, 61-72 (1989)

Tost, H., Jöckel, P., Kerkweg, A., Pozzer, A., Sander, R., Lelieveld, J.: Global cloud and precipitation chemistry and wet deposition: tropospheric model simulations with ECHAM5/MESSy1. Atmos. Chem. Phys. 7, 2733-2757 (2007) 
Zunckel, M., Saizar, C., Zarauz, J.: Rainwater composition in northeast Uruguay. Atmospheric Environment 37, 1601-1611 (2003) 
Click here to download table: GBERTRANDTables atm_chem 01_04_09.doc

Tables

\begin{tabular}{|l|cccccccccccc|}
\hline & $\begin{array}{c}\mathbf{E . C} \\
(\boldsymbol{\mu} \mathbf{S} / \mathbf{c m})\end{array}$ & $\mathbf{p H}$ & $\mathbf{H C O}_{\mathbf{3}}{ }^{-}$ & $\mathbf{C l}^{-}$ & $\mathbf{N O}_{\mathbf{3}}{ }^{-}$ & $\mathbf{S O}_{\mathbf{4}}{ }^{2-}$ & $\mathbf{P O}_{4}{ }^{3-}$ & $\mathbf{N a}^{+}$ & $\mathbf{N H}_{\mathbf{4}}{ }^{+}$ & $\mathbf{K}^{+}$ & $\mathbf{M g}^{\mathbf{2}^{+}}$ & $\mathbf{C a}^{2+}$ \\
\hline Arithmetic mean & 17.5 & 5.4 & 32.2 & 23.0 & 39.2 & 28.8 & 0.7 & 23.9 & 28.5 & 5.5 & 7.8 & 39.9 \\
Arithmetic s.d. & 14.3 & 0.7 & 38.1 & 29.5 & 47.4 & 27.2 & 3.9 & 32.7 & 19.5 & 6.7 & 8.2 & 60.0 \\
Minimum & 2.0 & 3.4 & 0.0 & 0.8 & 0.0 & 0.0 & 0.0 & 0.6 & 0.0 & 0.1 & 0.3 & 2.0 \\
Maximum & 96.0 & 7.1 & 200.0 & 211.4 & 324.9 & 134.8 & 37.4 & 250.5 & 92.5 & 41.2 & 54.0 & 413.3 \\
V-W mean & $\mathbf{1 2 . 6}$ & $\mathbf{5 . 1}$ & $\mathbf{2 7 . 5}$ & $\mathbf{1 1 . 5}$ & $\mathbf{2 5 . 8}$ & $\mathbf{2 4 . 6}$ & $\mathbf{0 . 3}$ & $\mathbf{1 2 . 0}$ & $\mathbf{2 4 . 4}$ & $\mathbf{3 . 1}$ & $\mathbf{5 . 2}$ & $\mathbf{3 3 . 8}$ \\
V-W s.d & 9.2 & 0.7 & 30.4 & 17.3 & 30.5 & 20.8 & 2.6 & 19.6 & 14.5 & 4.1 & 5.4 & 46.0 \\
\hline
\end{tabular}

Table 1: Major ionic constituents $\left(\mu \mathrm{eq} \cdot \mathrm{I}^{-1}\right.$ ) of the 217 sampled rains during the study period (from Nov-2005 to Nov-2007) 


\begin{tabular}{|c|ccc|}
\hline & F1 & F2 & F3 \\
\hline $\mathrm{H}_{3} \mathrm{O}^{+}$ & 0.111 & 0.041 & -0.420 \\
$\mathrm{HCO}_{3}{ }^{-}$ & 0.326 & 0.044 & $\mathbf{0 . 9 1 3}$ \\
$\mathrm{Cl}^{-}$ & 0.081 & $\mathbf{0 . 9 9 7}$ & 0.005 \\
$\mathrm{NO}_{3}{ }^{-}$ & $\mathbf{0 . 8 9 4}$ & 0.207 & -0.095 \\
$\mathrm{SO}_{4}{ }^{2-}$ & $\mathbf{0 . 8 7 4}$ & 0.257 & 0.125 \\
$\mathrm{PO}_{4}{ }^{3-}$ & 0.338 & -0.042 & 0.184 \\
$\mathrm{Na}^{+}$ & 0.124 & $\mathbf{0 . 9 2 0}$ & -0.088 \\
$\mathrm{NH}_{4}^{+}$ & $\mathbf{0 . 7 6 4}$ & 0.146 & 0.035 \\
$\mathrm{~K}^{+}$ & 0.341 & 0.260 & 0.300 \\
$\mathrm{Mg}^{2+}$ & 0.480 & $\mathbf{0 . 7 1 1}$ & 0.305 \\
$\mathrm{Ca}^{2+}$ & $\mathbf{0 . 5 3 2}$ & 0.184 & $\mathbf{0 . 6 0 6}$ \\
\% of total variance & 41.7 & 35.6 & 22.4 \\
\hline & Neut. & Marine & Terrestrial \\
\hline
\end{tabular}

Table 2: Varimax rotated factor loadings, total variance and the determination of the main different sources 


\begin{tabular}{|c|c|c|c|c|c|c|c|c|}
\hline & \multicolumn{2}{|c|}{ Sector 1} & \multicolumn{2}{|c|}{ Sector 2} & \multicolumn{2}{|c|}{ Sector 3} & \multicolumn{2}{|c|}{ Sector 4} \\
\hline Nb of events & \multicolumn{2}{|c|}{75} & \multicolumn{2}{|c|}{49} & \multicolumn{2}{|c|}{51} & \multicolumn{2}{|c|}{42} \\
\hline Height & \multicolumn{2}{|c|}{309} & \multicolumn{2}{|c|}{179} & \multicolumn{2}{|c|}{303} & \multicolumn{2}{|c|}{248} \\
\hline & V-W-Mean & V-W-Std dev & V-W-Mean & V-W-Std dev & V-W-Mean & V-W-Std dev & V-W-Mean & V-W-Std dev \\
\hline E.C. & 10.2 & 8.0 & 19.5 & 12.7 & 9.6 & 6.4 & 14.3 & 7.0 \\
\hline pH & 5.1 & 0.7 & 4.8 & 0.7 & 5.1 & 0.7 & 5.3 & 0.6 \\
\hline $\mathrm{HCO}_{3}^{-}$ & 24.1 & 28.9 & 28.3 & 31.5 & 26.6 & 37.2 & 32.2 & 21.3 \\
\hline $\mathrm{NO}_{3}^{-}$ & 16.0 & 15.2 & 52.3 & 53.8 & 16.9 & 13.6 & 29.7 & 22.4 \\
\hline $\mathrm{PO}_{4}{ }^{3-}$ & 0.0 & 0.2 & 1.4 & 5.6 & 0.0 & 0.3 & 0.2 & 2.2 \\
\hline $\mathrm{ssCl}^{-}$ & 14.7 & 23.6 & 13.8 & 30.1 & 8.6 & 11.7 & 8.0 & 6.6 \\
\hline $\mathrm{nssCl}^{-}$ & 0.3 & 11.4 & 0.7 & 18.0 & 0.3 & 10.6 & 0.1 & 11.6 \\
\hline $\mathrm{SSSO}_{4}{ }^{2-}$ & 1.7 & 23.3 & 1.9 & 20.5 & 1.1 & 10.8 & 1.0 & 6.2 \\
\hline $\mathrm{nsSSO}_{4}{ }^{2-}$ & 16.8 & 1.2 & 35.6 & 3.9 & 16.0 & 1.5 & 31.0 & 0.2 \\
\hline $\mathrm{Na}^{+}$ & 14.9 & 2.7 & 15.6 & 3.6 & 9.7 & 1.4 & 8.6 & 0.8 \\
\hline $\mathrm{NH}^{+}$ & 20.0 & 18.5 & 33.3 & 24.1 & 17.2 & 14.0 & 31.8 & 18.3 \\
\hline ssK $^{+}$ & 0.3 & 0.5 & 0.3 & 0.6 & 0.2 & 0.2 & 0.2 & 0.1 \\
\hline nssK $^{+}$ & 2.2 & 3.0 & 4.7 & 6.6 & 2.2 & 2.8 & 3.1 & 2.9 \\
\hline $\operatorname{ssMg}^{2+}$ & 3.0 & 4.5 & 2.8 & 3.2 & 2.0 & 2.4 & 1.9 & 1.5 \\
\hline nssMg $^{2+}$ & 2.0 & 2.8 & 4.7 & 5.4 & 2.1 & 3.2 & 3.2 & 2.7 \\
\hline $\mathrm{ssCa}^{2+}$ & 0.7 & 1.0 & 0.7 & 1.3 & 0.4 & 0.5 & 0.4 & 0.3 \\
\hline $\mathrm{nssCa}^{2+}$ & 23.9 & 44.6 & 53.2 & 66.0 & 28.4 & 40.4 & 36.8 & 27.8 \\
\hline
\end{tabular}

Table 3: Weighted mean value $\left(\mu \mathrm{eq} \cdot \mathrm{I}^{-1}\right.$ ) of major ionic rain components for the four meteorological sectors $(\mathrm{ss}=\mathrm{sea}$ salt $/ \mathrm{nss}=\mathrm{non}$ sea-salt) 


\begin{tabular}{|c|cccccccc|}
\hline Event & $\begin{array}{c}\text { Long-range } \\
\text { provenance }\end{array}$ & Duration & Height $(\mathbf{m m})$ & $\begin{array}{c}\text { Number of } \\
\text { fractions }\end{array}$ & $\begin{array}{c}\text { Mean Wind } \\
\text { speed (m/s) }\end{array}$ & $\begin{array}{c}\text { Mean Wind } \\
\text { direction } \\
\text { (degrees) }\end{array}$ & $\begin{array}{c}\text { Mean E.C. } \\
(\boldsymbol{\mu S} / \mathbf{c m})\end{array}$ \\
\hline $\mathbf{2 3 - 2 4 / 0 3 / 0 6}$ & Sector 1 & $2 \mathrm{~h} 15$ & 7.3 & 8 & $5.5 \pm 0.7$ & $167 \pm 8$ & $16.3 \pm 8.0$ \\
$\mathbf{1 1 / 0 4 / 2 0 0 6}$ & Sector 2 & $4 \mathrm{~h} 00$ & 7.1 & 8 & $3.3 \pm 1.1$ & $269 \pm 60$ & $6.5 \pm 2.9$ & $5.9 \pm 0.2$ \\
$\mathbf{0 6 / 0 5 / 2 0 0 6}$ & Sector 3 & $4 \mathrm{~h} 30$ & 9.7 & 10 & $2.0 \pm 1.6$ & $134 \pm 75$ & $18.0 \pm 10.0$ & $5.2 \pm 0.4$ \\
$\mathbf{0 7 / 0 5 / 2 0 0 6}$ & Sector 4 & 1 h 00 & 9.3 & 10 & $2.5 \pm 1.6$ & $117 \pm 63$ & $7.6 \pm 2.9$ \\
\hline
\end{tabular}

Table 4: Mean characteristics of the four fractionated events 


\section{Figures}

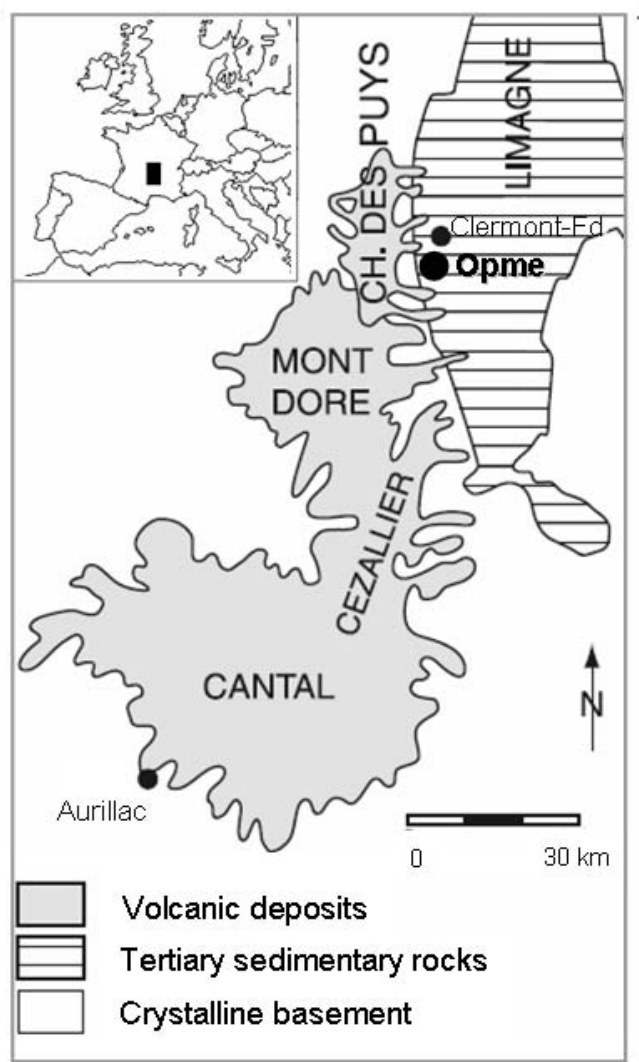

Fig. 1 Location and geological settings of the studied area

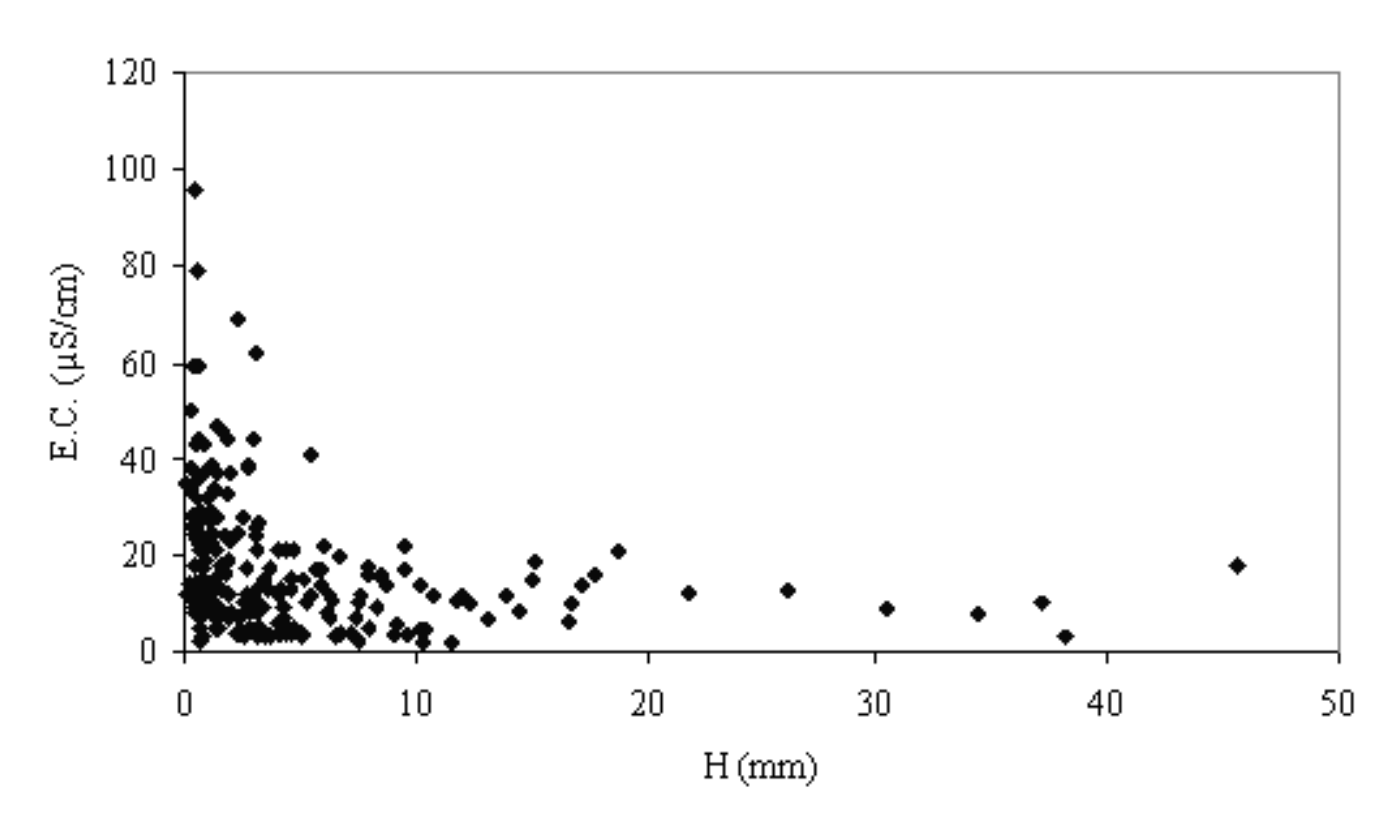

Fig. 2 Relationship between precipitation height $(\mathrm{mm})$ and E.C. $(\mu \mathrm{S} / \mathrm{cm})$ of rainwater 


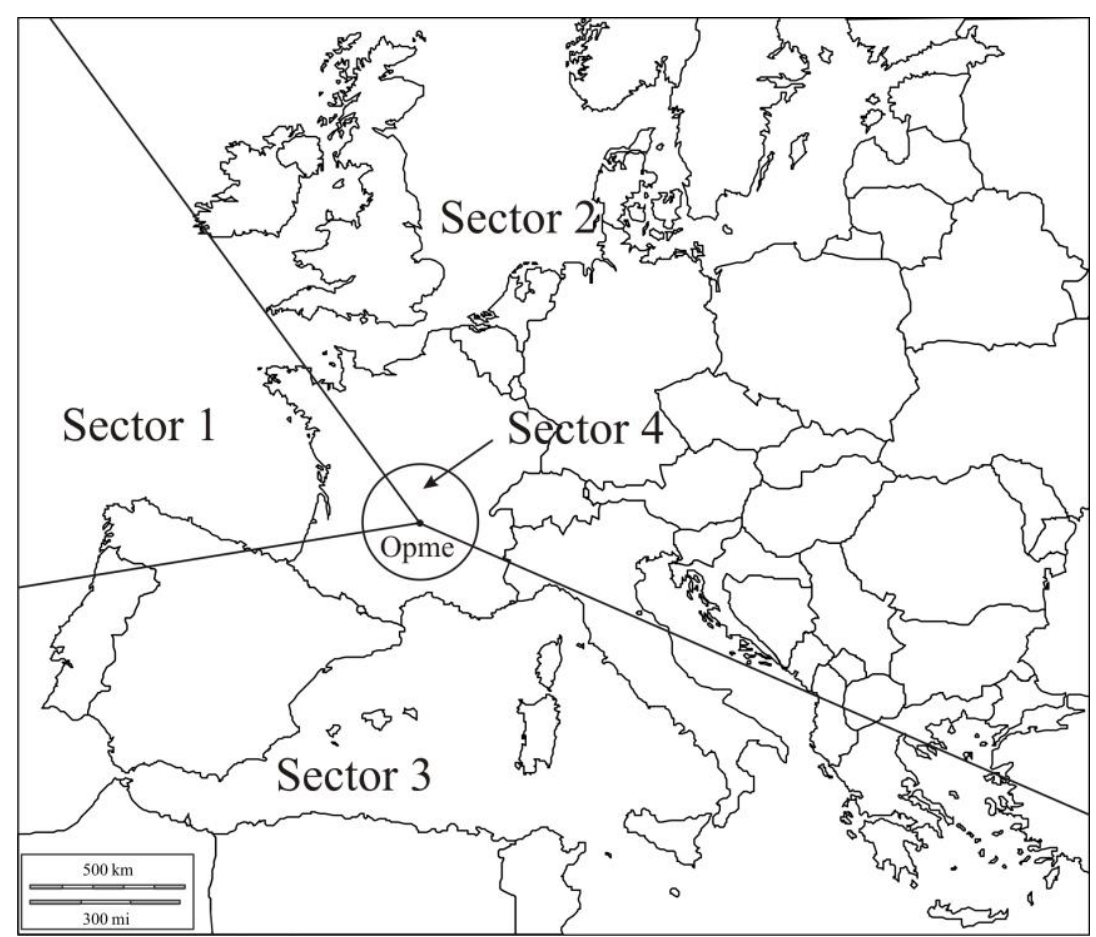

Fig. 3 Main sectors for air masses trajectories arriving at Opme: (1) West, (2) North and East, (3) South including Iberian and Italian peninsulae and (4) Local 

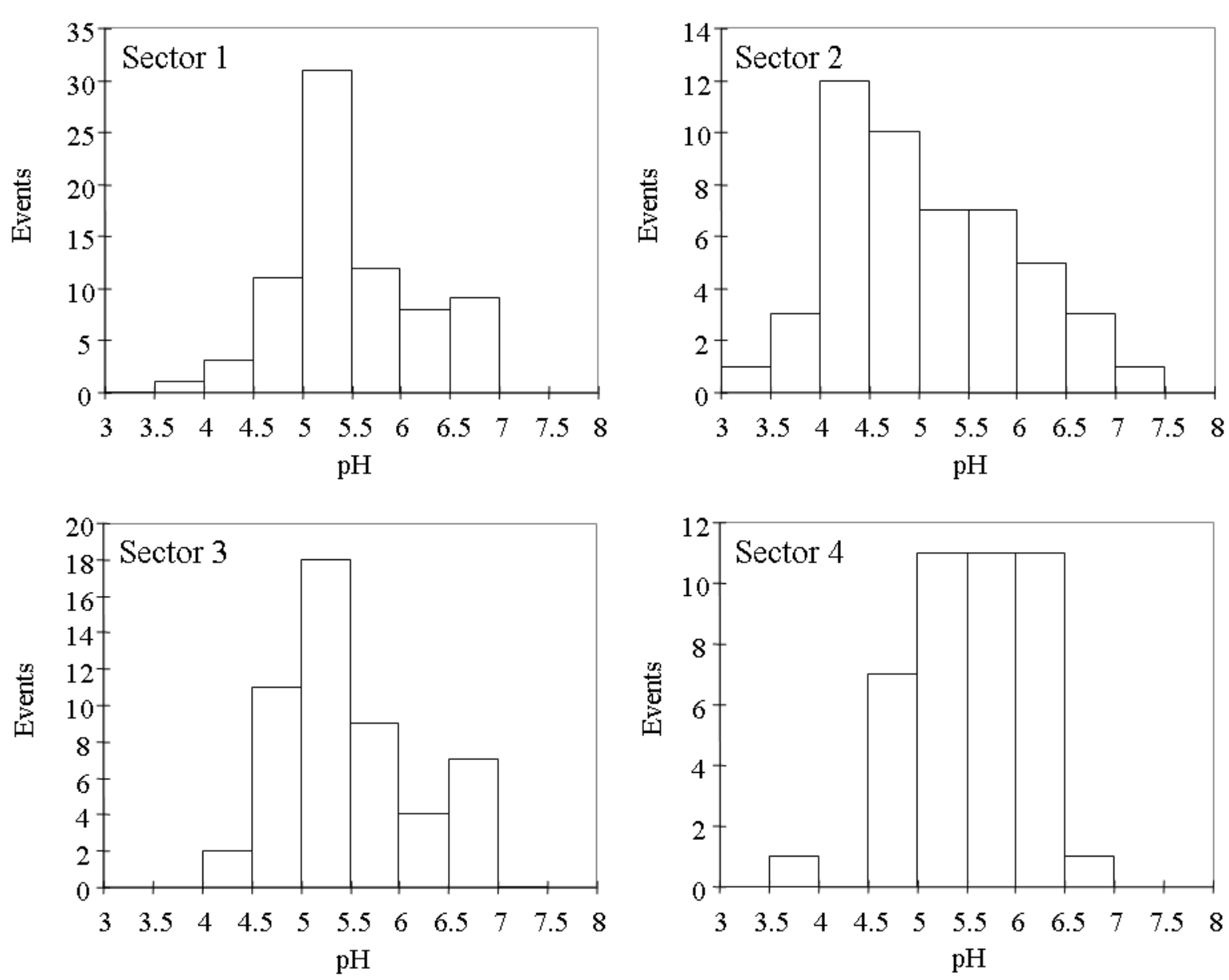

Fig. 4 pH distribution for the four meteorological sectors 

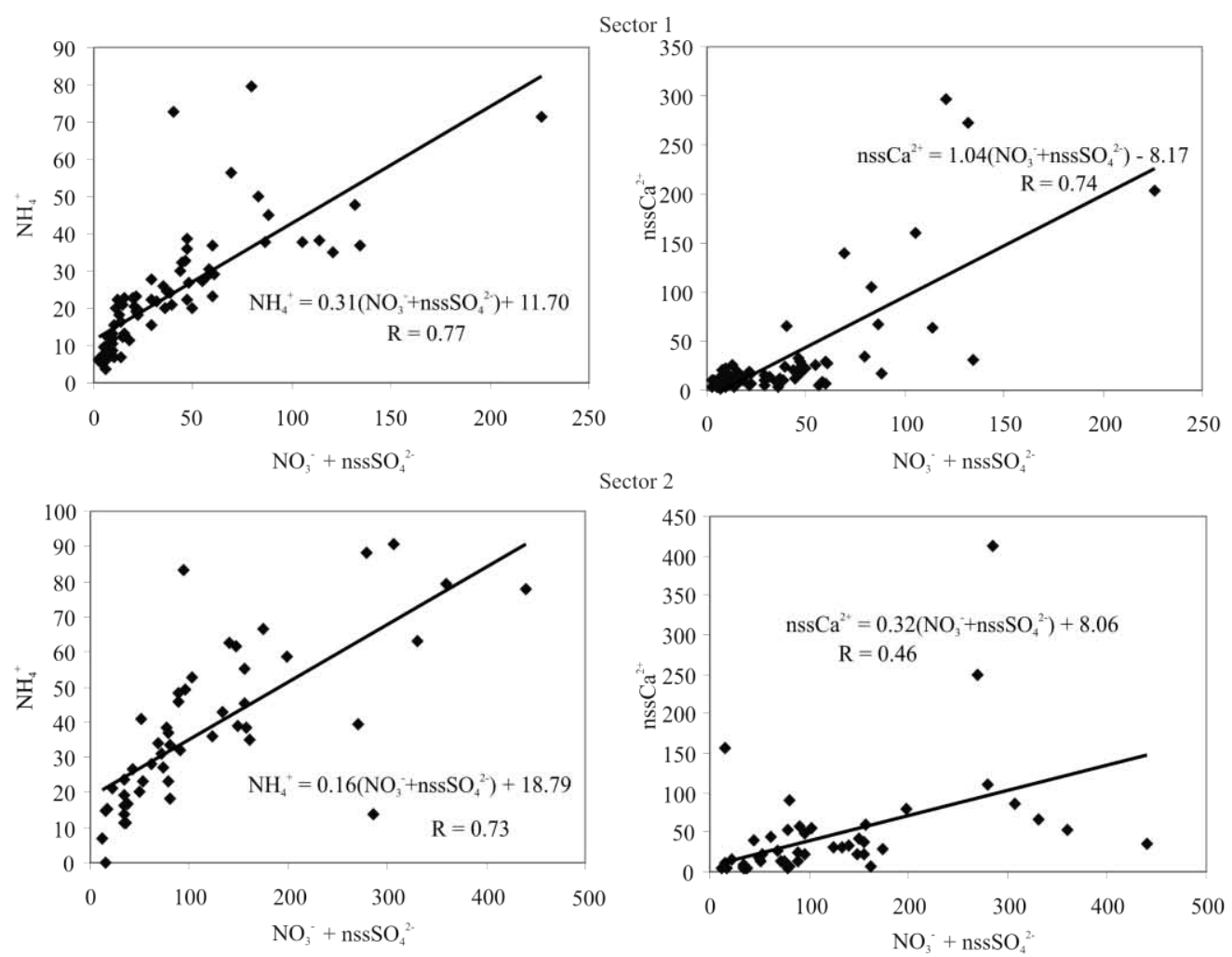

Sector 3
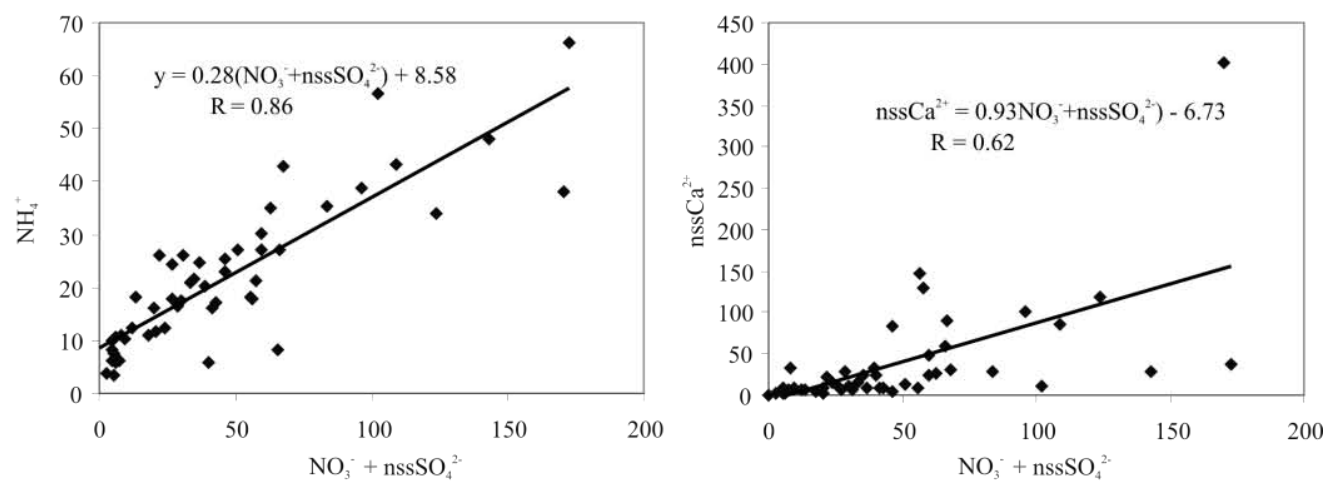

Sector 4
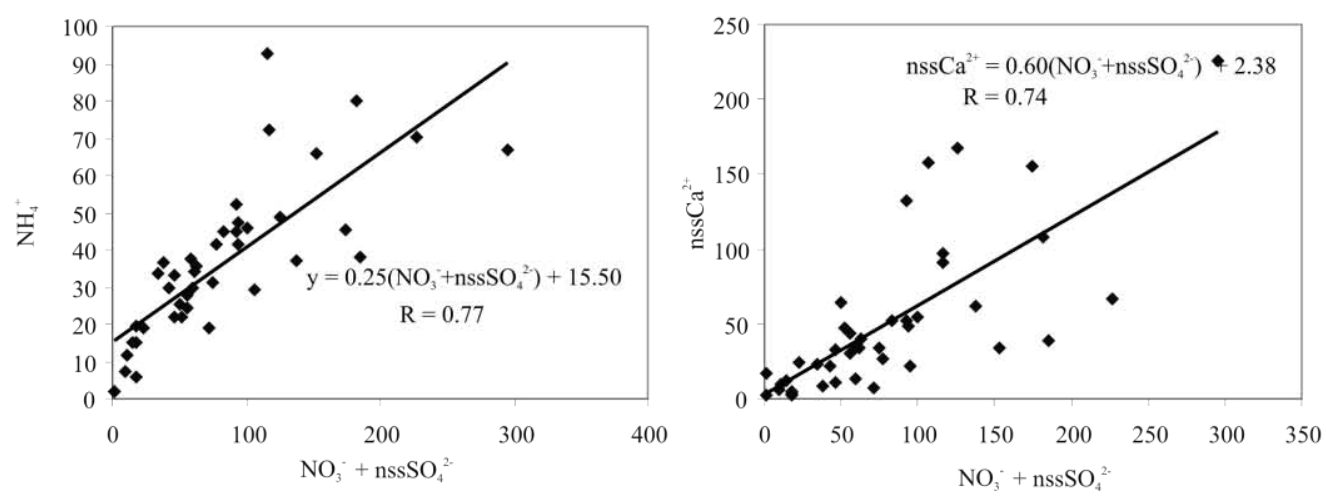

Fig. 5 Non sea-salt $\mathrm{Ca}^{2+}$ versus $\left[\mathrm{NO}_{3}{ }^{-}+\mathrm{nsSSO}_{4}{ }^{2-}\right]$ and $\mathrm{NH}_{4}{ }^{+}$versus $\left[\mathrm{NO}_{3}{ }^{-}+\mathrm{nsSSO}_{4}{ }^{2-}\right]$ for the four meteorological sectors 


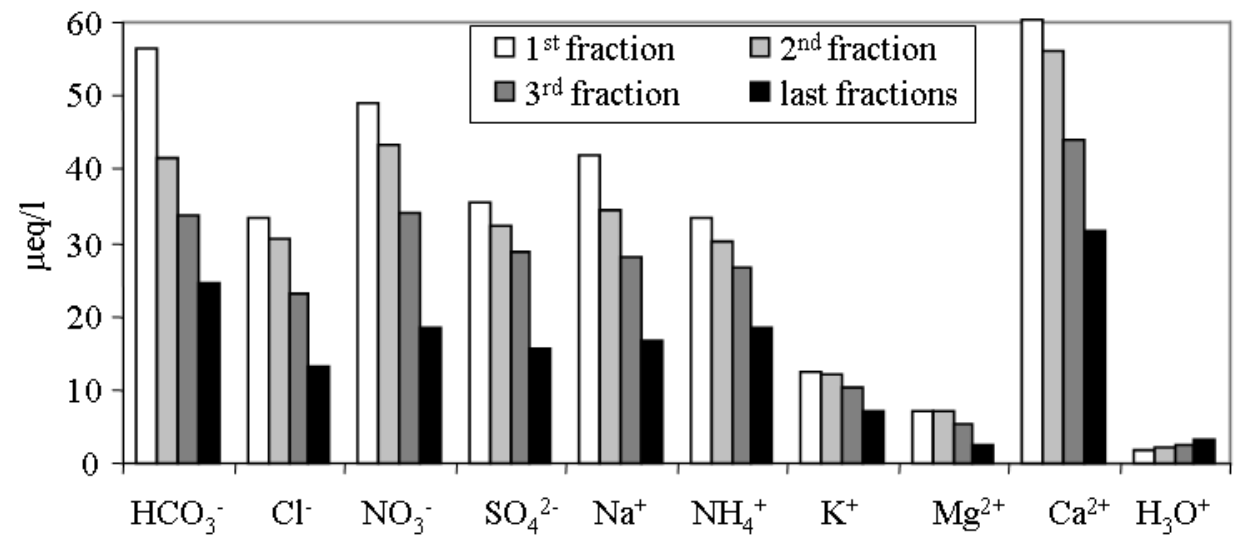

Fig. 6 Mean chemical content evolution for the 29 fractionated sampled events 

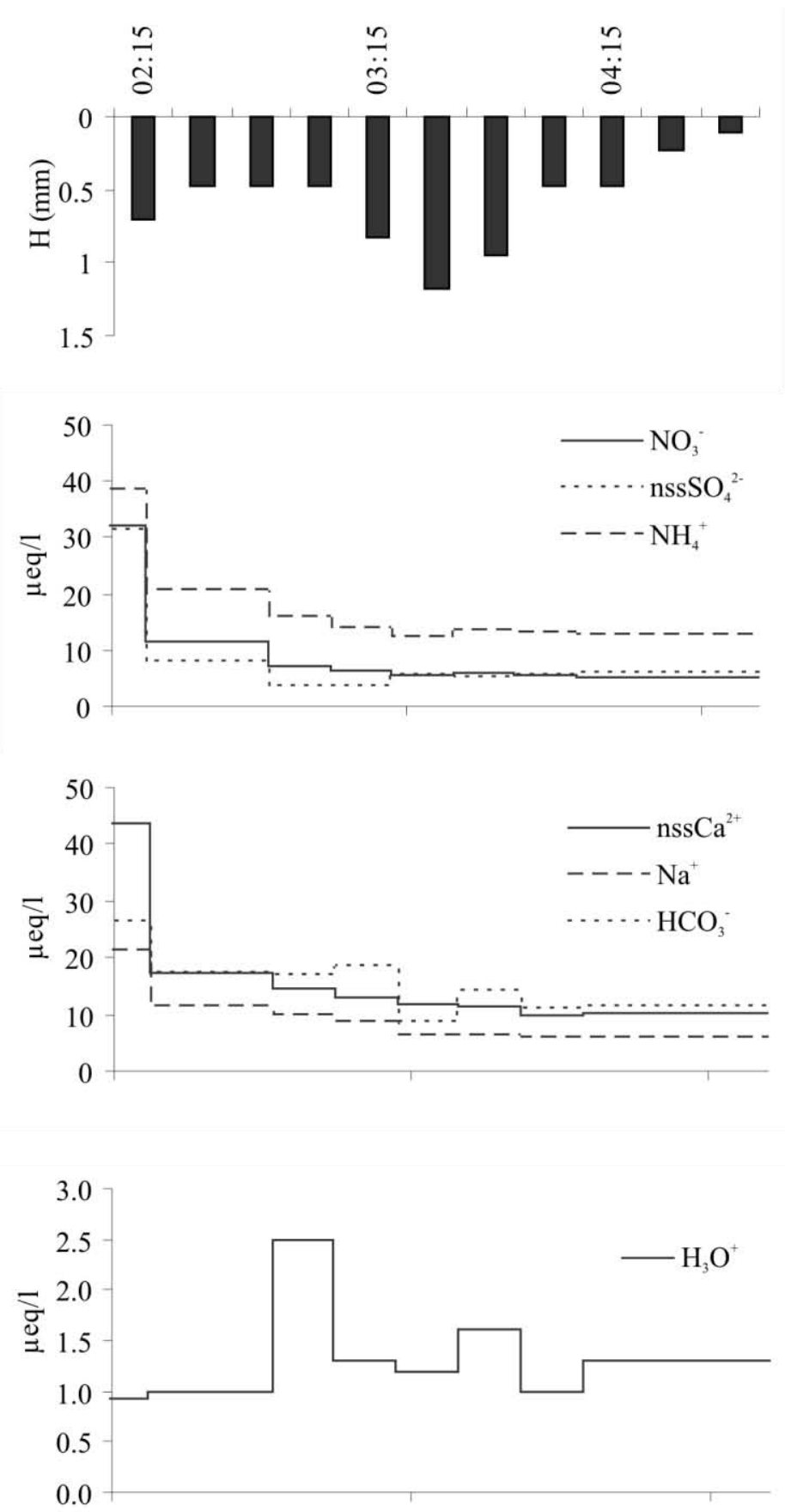

Fig. 7 Evolution of the chemical content and rainfall height for the 23-24/03/2006 event coming from sector 1 

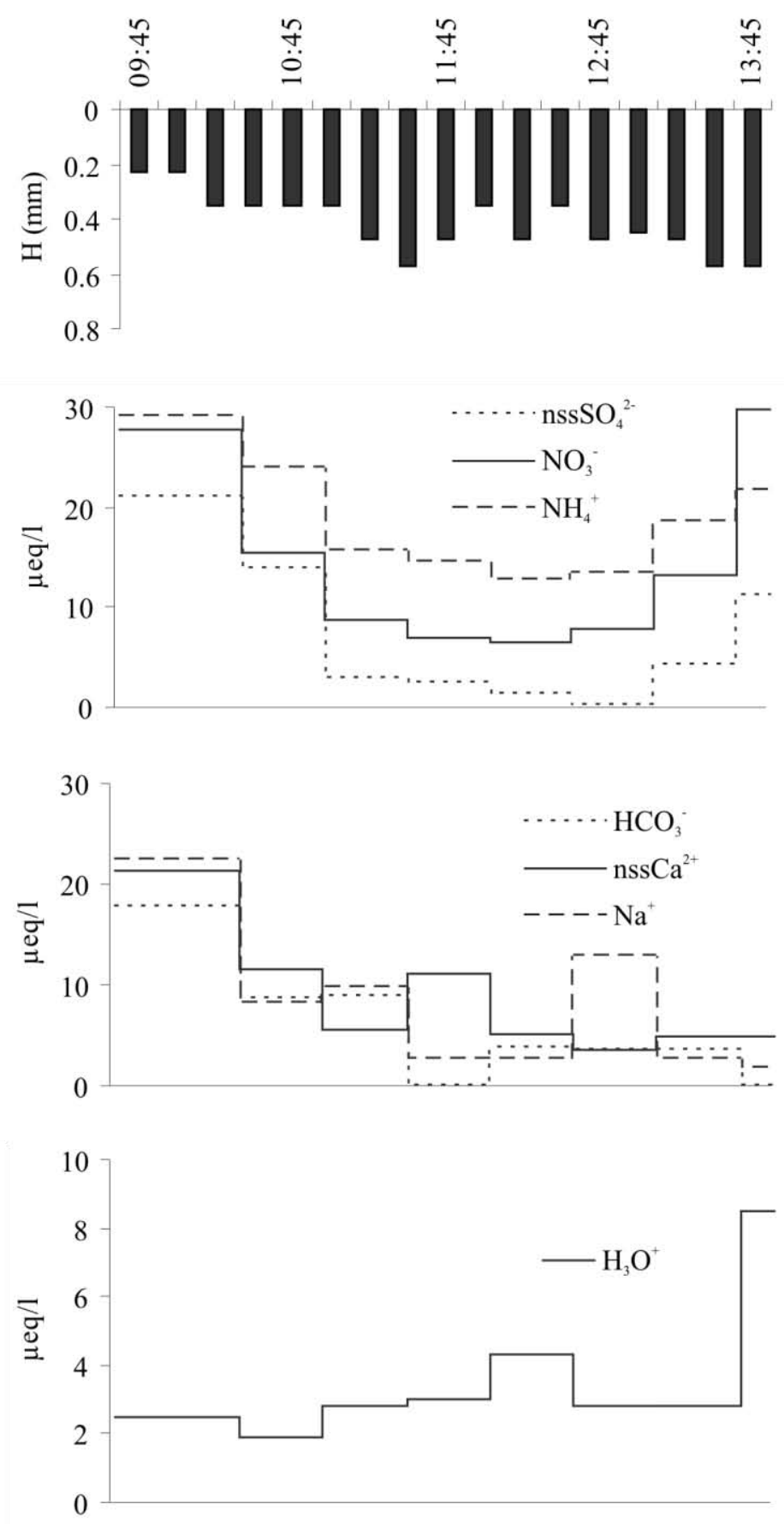

Fig. 8 Evolution of the chemical content and rainfall height for the 11/04/2006 event coming from sector 2 

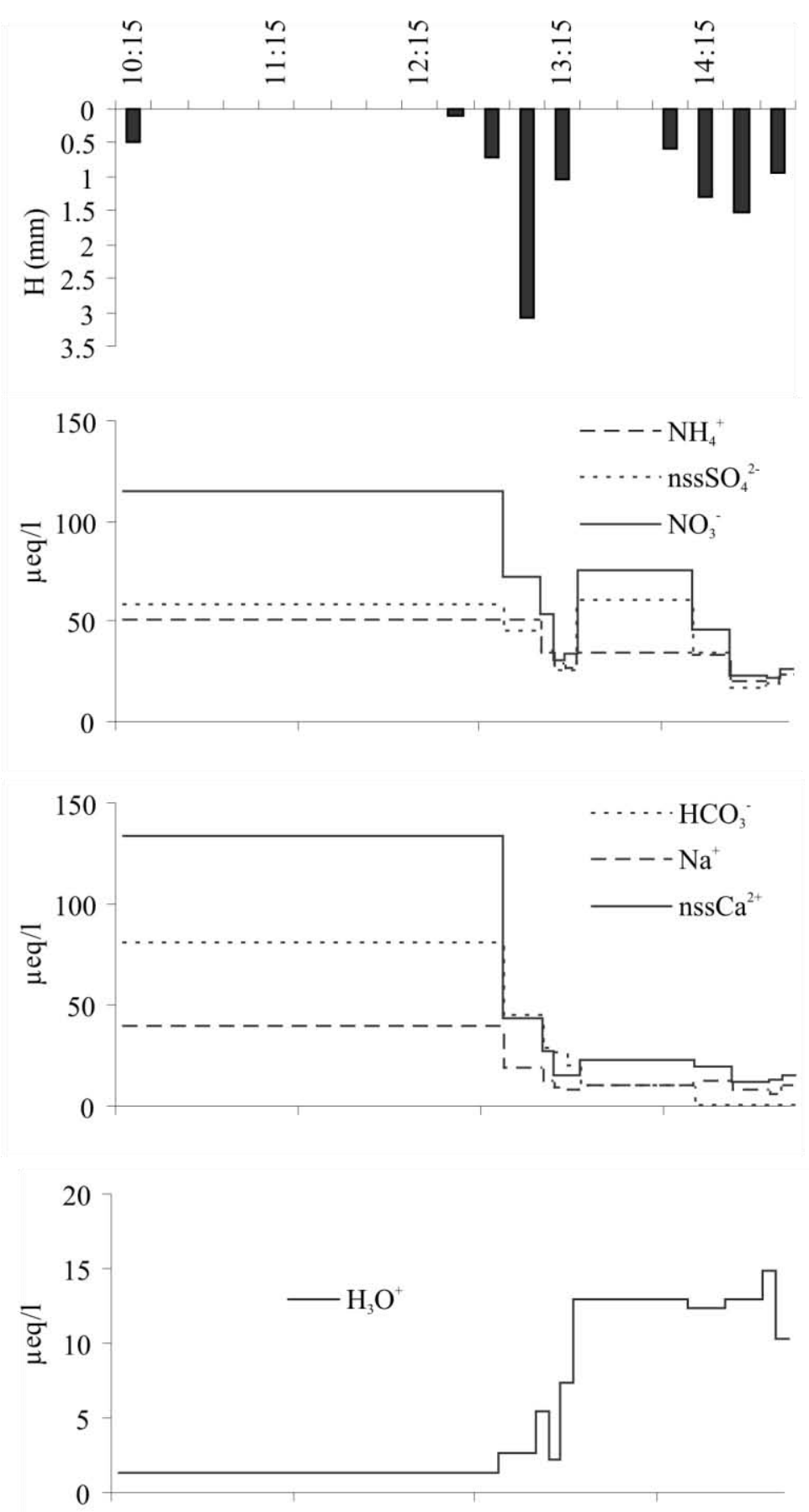

Fig. 9 Evolution of the chemical content and rainfall height for the 06/05/2006 event coming from sector 3 

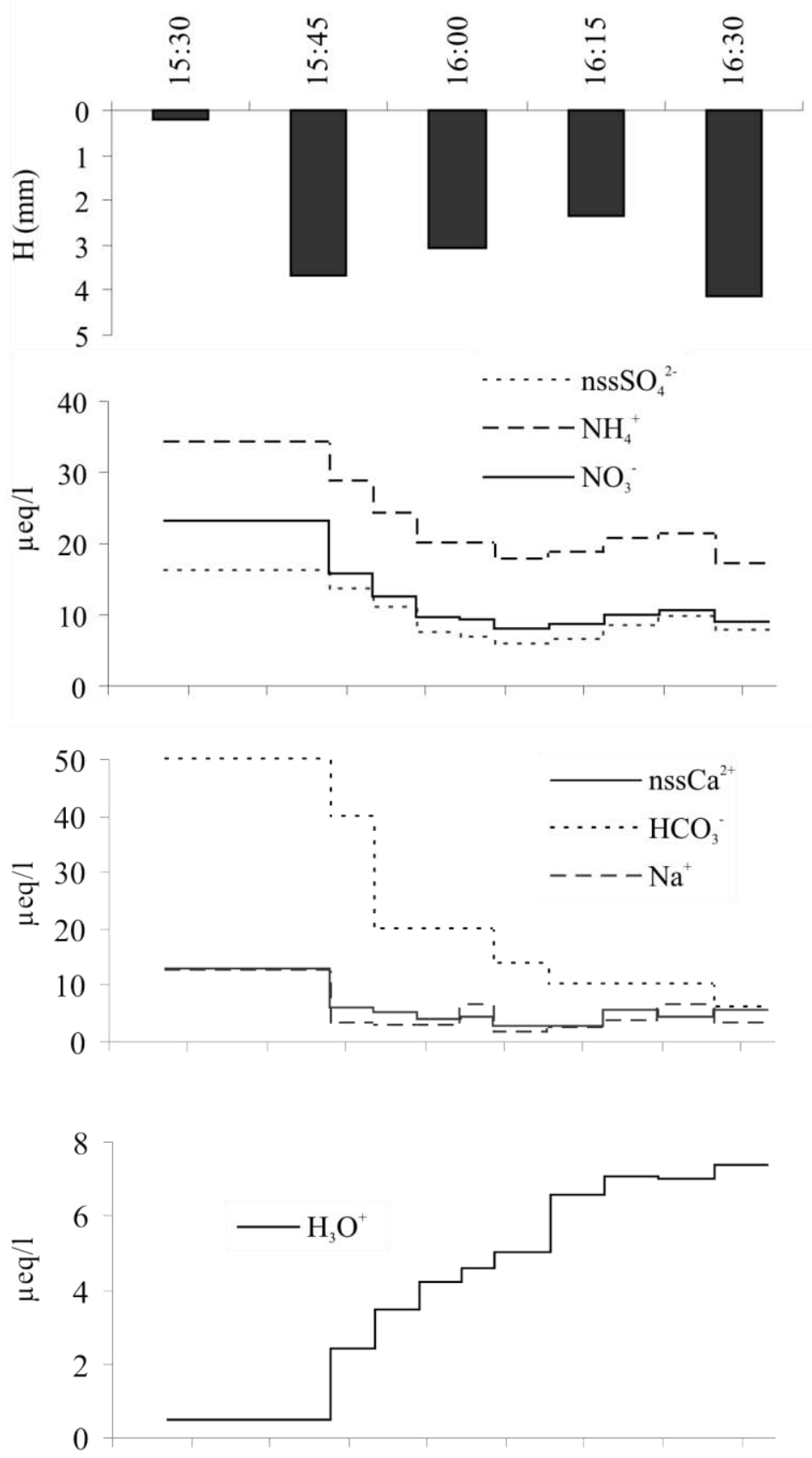

Fig. 10 Evolution of the chemical content and rainfall height for the 07/05/2006 event coming from sector 4 